\title{
Physical and Mechanical Properties of Three Commercially Grown Banana (Musa acuminata Colla) Cultivars in Sri Lanka
}

W.M.C.B. Wasala ${ }^{*}$, D.A.N. Dharmasena ${ }^{1}$, T.M.R.Dissanayake ${ }^{2}$ and B.M.K.S. Thilakarathne ${ }^{2}$

Postgraduate Institute of Agriculture

University of Peradeniya

Peradeniya, Sri Lanka

\begin{abstract}
Physical and mechanical properties of banana (Musa acuminata Colla) are necessary to design handling and packaging equipment, and for safe transportation. The postharvest losses of banana in Sri Lanka are about $30 \%$ and the mechanical damage during transport and handling contributes largely for these losses. Further, about $97 \%$ of fruits are handled by the traditional marketing channels under poor postharvest handling practices and therefore, safe handling and transport is of prime importance at present. The bulk transportation is generally considered as the most cost effective method. Therefore, this study was conducted to assess the physical and mechanical properties related to handling and transport of commercially grown local banana cultivars namely, Seeni, Embul and Kolikuttu. The moisture content, linear dimensions of bunches and fruits, sphericity and aspect ratio of fruits, bulk density and true density, coefficient of static friction and the angle of repose on different surfaces such as wood, steel and Styrofoam, and fruit firmness were measured for the above three cultivars at the harvest maturity. The average bunch length of the banana cultivars Embul and Kolikuttu were higher than those of Seeni. The geometrical mean diameters of Embul and Kolikuttu fruits were also higher than Seeni $(p<0.05)$. The average fruit length of Embul, Seeni and Kolikuttu cultivars were $10.5( \pm 0.86), 10.5( \pm 0.86)$ and $14.3( \pm 1.66) \mathrm{cm}$, respectively. The fruit finger sphericities were between 0.37-0.38 for all cultivars tested ( $p>0.05)$. The bulk density of fruits and hands were higher than those of the whole bunch. The lowest coefficient of static friction was on Styrofoam and the highest was on a wooden surface. There was no significant difference of firmness of mature green banana fruits among the cultivars ( $p>0.05$ ). This data could be used for appropriate designs and improvements of postharvest handling and packaging in future.
\end{abstract}

Keywords: physical properties, fruit finger, banana bunch, density, harvest maturity

\section{INTRODUCTION}

Banana (Musa acuminata Colla) is the most widely cultivated and most important fruit in Sri Lanka due to its high economic returns throughout the year (Kudagamage et al., 2002) and is one of the widely grown fruit crops in tropical countries due to worldwide consumer demand. About 50,000 ha of land are under banana cultivation in Sri Lanka with an annual production of about 45,000 tons (Hirimburegama et al. 2004), while in global scale It has also subsumed the third place in the world fruits in terms of volume of production.

\footnotetext{
Department of Agricultural Engineering, Faculty of Agriculture, University of Peradeniya, Peradeniya Sri Lanka

2 Institute of Postharvest Technology, Jayanthi Mawatha, Anuradhapura, Sri Lanka

* Author for correspondence: wasala73@yahoo.com
} 
Banana is a climacteric fruit and perishable in nature having relatively high postharvest losses of about $20-30 \%$ (Ekanayake and Bandara, 2002; Sarananda, 2000), mainly due to physical damages caused during handling and transportation. Although banana is harvested at the mature green stage, the external appearance of the ripe banana displayed at the retail shops may be poor due to excessive bruising, abrasion and diseases resulting from improper handling throughout the supply chain (Sarananada, 2000). Bananas are usually packed in trucks without using proper packaging or any cushioning or lining materials in the traditional distribution channels, which accounts for about $97 \%$ of the local marketing (Dharmasena and Sarananda, 2012). The mechanical damage not only leads to postharvest losses but also create various physiological stresses to fruits leading to physiological and morphological changes (Shewfelt, 1987), and is also identified as the major cause of postharvest losses even in international marketing channels. Therefore, identification, development and introduction of appropriate postharvest handling and packaging techniques for banana are of paramount importance to reduce the postharvest losses of banana in Sri Lanka. This will ensure the required final fruit quality and the maximum shelf life while minimizing the environmental pollution due to fruit waste, and saving one third of the agricultural inputs including water used for crop production.

Biological materials have unique characteristics different from engineering materials. Design of machines, tools or developing proper handling and storage mechanisms for agricultural produce requires an understanding of their physical properties (Stroshine, 2005). The bulk density and porosity are useful in packaging, transportation and separation mechanisms (Kachru et al., 1995), while shape and physical dimensions such as major, intermediate and minor diameters, unit mass, volume and separate foreign materials are important in sorting and grading of fruits and vegetables (Stroshine, 2005). The knowledge of frictional properties is required for the designing of handing equipment and storage structures (Mohsenin, 1970; Peleg and Bagley, 1983). The static coefficient of friction on different surfaces may be useful in the separation processes and for the transportation of fruits (Ikegwu and Ekwu, 2009). Kachru et al. (1995), investigated the physical and mechanical characteristics of two varieties of green mature banana fruits and observed that some properties are different between two varieties thus, suggesting the importance of the knowledge on physical and mechanical properties of banana fruits of different varieties in order to introduce proper postharvest handling and packaging technologies.

The objective of the present study was to assess the physical and mechanical properties of bunches, hands and fingers of three commercially grown banana cultivars in Sri Lanka that could be used to introduce appropriate handling, packaging and transportation practices in the local distribution channels.

\section{MATERIALS AND METHODS}

\section{Sample collection and interim storage}

Three major local banana (Musa accuminara Colla) cultivars grown in Sri Lanka namely, 'Embul' (AAB), 'Seeni' (ABB) and 'Kolikuttu' (AAB) were used in this study. The fully mature (3/4 quarters full) green banana bunches of the three cultivars were procured from Thambuttegama in the Dry Zone of Sri Lanka and safely transported to the laboratory of the Institute of Postharvest Technology at Anuradhapura. The experiments were carried out at a room temperature range of $27-32{ }^{\circ} \mathrm{C}$, and relative humidity between $69-76 \%$. 


\section{Determination of moisture content}

The moisture content of banana fruits was determined by placing $3.5 \mathrm{~mm}$ thick banana slices (average weight of $5.47 \pm 1.09 \mathrm{~g}$ ) with peel in a single layer in an aluminum dish, and drying in a hot air oven at $130 \pm 1{ }^{\circ} \mathrm{C}$ for $1.5 \mathrm{~h}$ as reported by Kachru et al. (1995).

\section{Measurement of linear dimensions}

The fruit size in terms of the three linear dimensions namely, length (a), breadth (b) and thickness (c) were measured using a Vernier caliper (VOLVOX NC 3P 23; accuracy 0.01 $\mathrm{mm}$ ). The short (blossom end), middle and stalk end (top) diameters and the length of banana bunches were recorded (Fig. 1).

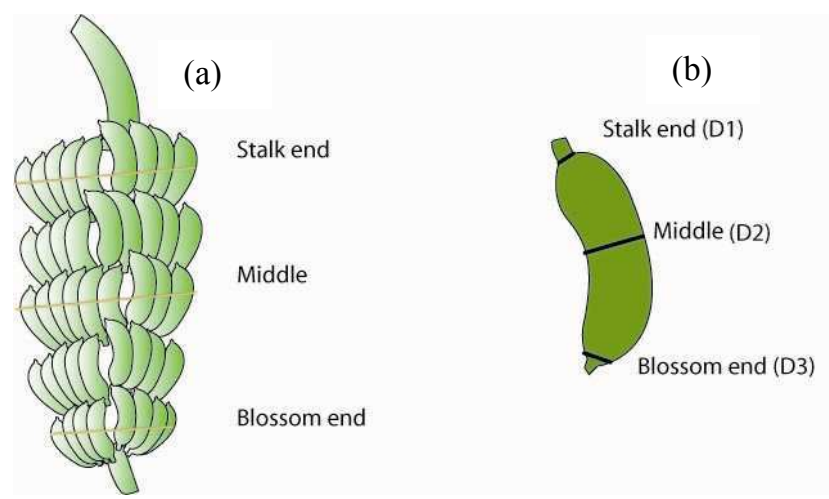

Fig. 1. Major diameters of banana bunch (a) and banana fruit/finger (b)

The Geometric Mean Diameter (GMD) was calculated using the Equation 1. The external (Lo) and internal (Li) lengths of the banana fingers were measured using a flexible ruler (Fig. 2). The perpendicular diameters or the maximum and minimum cross sectional diameters ( $\mathrm{W}$ and T, respectively) were also measured (Fig. 3).

$$
\text { GMD }=(\text { MID x MOD x MAD })^{1 / 3}----[1]
$$

Where, GMD = geometric mean diameter $(\mathrm{cm}) ; \mathrm{MID}=$ short diameter $(\mathrm{cm}) ; \mathrm{MOD}=$ middle diameter $(\mathrm{cm})$; MAD = long diameter $(\mathrm{cm})$.

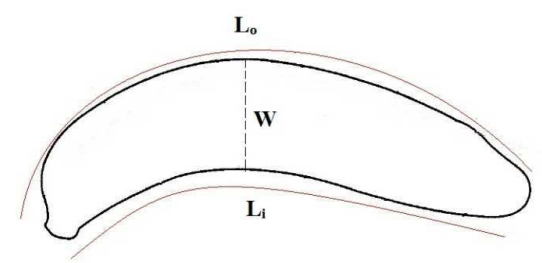

Fig. 2. Major dimensions of a banana fruit diameters

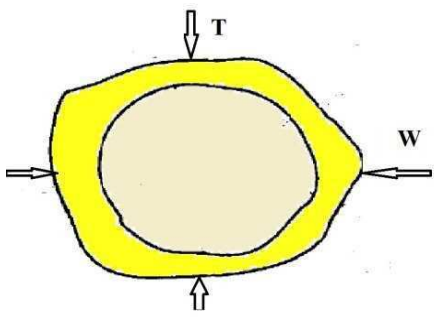

Fig. 3. The perpendicular $(W, T)$ of a banana fruit 


\section{Sphericity and aspect ratio}

Sphericity may be defined as the ratio of the diameter of a sphere of the same volume as that of the particle and the diameter of smallest circumscribing sphere or generally the largest diameter of the particle (Sahay and Singh, 2005). The fruit shape of banana was expressed in terms of its sphericity and the aspect ratio. The sphericity ( $\mathrm{Sp}$ ) was calculated using the Equation 2 (Mohsenin, 1986).

$$
S_{p}=\frac{(a b c)^{1 / 3}}{a} \quad \text {----------------------- Equation 2 }
$$

The aspect ratio $\left(\mathrm{R}_{\mathrm{a}}\right)$ was calculated as recommended by Maduako and Faborode (1990) using the Equation 3.

$$
R_{a}=\frac{b}{a} \times 100 \%
$$

For both equations 2 and $3, \mathrm{a}=$ length $(\mathrm{cm}), \mathrm{b}=$ width $(\mathrm{cm})$ and $\mathrm{c}=$ thickness $(\mathrm{cm})$.

\section{Mass and volume measurement}

The mass of individual fruits/fingers was determined using an OHAUS ARA520 electronic balance (ARA520, OHAUS, USA; accuracy $0.01 \mathrm{~g}$ ). The volume of banana fruit fingers was determined by the water displacement method. Randomly selected 18 fruits from three bunches were weighed. The fruit was first weighed on the scale in air and then forced into water by means of a sinker rod. A beaker half-filled with water is weighed and the weight of the container and water was deducted from the second reading of the scale with the fruit submerged, to calculate the weight of the displaced water. The volume of banana was calculated using the Equation 4 (Mohsenin, 1986);

$$
V=\frac{W_{d w}}{D_{w}} \quad \text {--------------------------------- Equation } 4
$$

where, $V$ and $W_{\mathrm{d} w}$ are volume of banana and weight of displaced water, respectively, and $D_{w}$ is the density of water.

The same experiment was carried out for banana hands. The mass of banana bunches was determined using a 'Bestech' scale balance to an accuracy of $0.5 \mathrm{~kg}$. Volume of banana bunches was determined by the water displacement method using a cylindrical plastic bucket.

\section{Determination of the true density}

True density of banana fruits was determined by the ratio of weight to volume (Mohsenin, 1986). The mass of individual banana bunches, hands and fingers was measured using a weighing balance, and the volume was measured by water displacement method. Densities $\left(\mathrm{kg} \mathrm{m}^{-3}\right)$ were calculated by using the Equation 5 (Mohsenin, 1986);

$$
\boldsymbol{\rho}_{f}=\frac{M_{a}}{V} x \boldsymbol{\rho}_{w} \text { - }
$$


where, $\boldsymbol{\rho}_{f}$ is the true density of banana, $\boldsymbol{\rho}_{w}$ is water density $\left(\mathrm{kg} / \mathrm{m}^{3}\right)$ and $M a$ is mass of banana in air.

\section{Measurement of bulk density}

The bulk density of banana was determined using the mass/volume relationship (AOAC, 1984; Owolarafe et al., 2007). An empty plastic container of predetermined volume was filled with banana hands/fruits separately and the mass of filled amount was weighed using an electronic balance (OHAUS, ARA520) to an accuracy of $0.01 \mathrm{~g}$. Densities $\left(\mathrm{kg} / \mathrm{m}^{3}\right)$ were calculated using the Equation 6 (Mohsenin, 1986).

$$
\boldsymbol{\rho}_{\boldsymbol{b}}=\frac{M}{\boldsymbol{V}} \text {--------------------------------------------- [6]}
$$

Where, $\rho_{b}$ is the bulk density $\left(\mathrm{kg} \mathrm{m}^{-3}\right), \mathrm{M}$ and $\mathrm{V}$ are the mass of fruit/hand $(\mathrm{kg})$, and the container volume $\left(\mathrm{m}^{3}\right)$, respectively. This method is reported by Fraser et al. (1978).

The bulk density of banana bunches was determined by stacking bunches in a space with known volume and weighing the mass of stacked amount of bunches. The bulk density (kg $\left.\mathrm{m}^{-3}\right)$ was calculated using the Equation 6 , taking the volume $(V)$ as the packed space $\left(\mathrm{m}^{3}\right)$.

\section{Determination of the coefficient of static friction}

The coefficient of static friction was obtained for three different surfaces namely, galvanized steel, wood and Styrofoam by using an inclined plane apparatus as described by Dutta et al. (1988). The inclined plane was gently raised and the angle of inclination at which the sample started sliding was red off from the protractor with a sensitivity of one degree. The tangent of the angle was reported as the coefficient of static friction using the Equation 7;

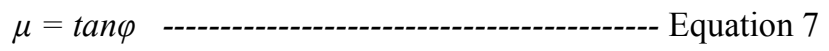

where, $\mu$ is the coefficient of static friction and $\varphi$ is the tilt angle of the friction surface. All the friction experiments were conducted in three replications for each surface.

\section{Fruit firmness}

Firmness of green banana was measured using a digital fruit firmness tester with a cylindrical shaped probe of $4 \mathrm{~mm}$ in diameter. Three readings were taken for each fruit at short, middle and long points. Eighteen fruits from one bunch representing the whole bunch were taken. These samples were collected from five banana bunches. Before measuring firmness, fruits were stored at $27{ }^{\circ} \mathrm{C} \pm 1$ for $24 \mathrm{hrs}$ in an incubator simulating the field conditions at harvesting as described by Dharmasena and Rathnayake (2004).

\section{Data analysis}

The experiment was conducted in a Complete Randomized Design (CRD). Data gathered were analyzed using Analysis of Variance (ANOVA) by Statistical Analysis System (SAS, 1994). Differences between treatment means were compared using Duncan's Multiple Range Test at $\mathrm{p}=0.05$. 


\section{RESULTS AND DISCUSSION}

\section{Moisture content of banana}

The average moisture content of Embul, Seeni and Kolikuttu cultivars of banana at the harvest maturity are shown in Table 1 . Results indicated that the moisture contents of three banana cultivars are not significantly different $(\mathrm{p}>0.05)$. Similar values were reported by Kachru et al. (1995), for some banana varieties grown in India at maturity. Ikegwu and Ekwu (2009) reported that the moisture content of fruits influences the number of engineering properties and Fraser et al. (1978), reported that the moisture content of agricultural produce influences their bulk density.

Table 1. Moisture content of three banana cultivars

\begin{tabular}{cccc}
\hline Property & \multicolumn{3}{c}{ Banana cultivars } \\
\hline \multirow{2}{*}{ Moisture content } & Embul & Seeni & Kolikuttu \\
Moisture content & $351.66 \pm 0.32$ & $72.46 \pm 2.42$ & $75.97 \pm 0.25$ \\
\hline
\end{tabular}

Data represented as mean \pm standard deviation; Values of different cultivars are not significantly different at $\mathrm{p}=0.05$.

\section{Geometrical properties of banana}

A summary of physical dimensions of banana bunches and fruits of Embul, Seeni and Kolikuttu cultivars are shown in Tables 2 and 3.The Embul and Kolikuttu cultivars showed significantly higher $(\mathrm{p}<0.05)$ average bunch length than that of the Seeni variety (Table 2). The geometrical mean diameters of Embul and Kolikuttu fruits are higher than that of Seeni fruits. Usually the bunch characteristics vary among banana cultivars (Al-Hosni et al., 2010). The bunch dimensions are important in designing packaging for bulk transportation of whole banana bunches (Wills et al., 1989).

Table 2. Linear dimensions of bunches of three local banana cultivars

\begin{tabular}{|c|c|c|c|}
\hline \multirow{2}{*}{ Property } & \multicolumn{3}{|c|}{ Banana cultivars } \\
\hline & Embul & Seeni & Kolikuttu \\
\hline Length $(\mathrm{cm})$ & $75.00^{\mathrm{a}}$ & $55.00^{\mathrm{b}}$ & $65.69^{\mathrm{a}}$ \\
\hline Diameter at tail $(\mathrm{cm})^{*}$ & $27.67 \pm 1.91$ & $26.81 \pm 1.46$ & $30.05 \pm 1.27$ \\
\hline Diameter at middle $(\mathrm{cm})^{*}$ & $31.70 \pm 3.02$ & $26.49 \pm 1.94$ & $31.16 \pm 1.27$ \\
\hline Diameter at top $(\mathrm{cm})^{*}$ & $32.34 \pm 3.72$ & $27.57 \pm 1.02$ & $33.07 \pm 2.26$ \\
\hline Geometrical mean diameter $(\mathrm{cm})$ & $30.21^{\mathrm{a}}$ & $26.96^{\mathrm{b}}$ & $31.42^{\mathrm{a}}$ \\
\hline
\end{tabular}

*Data presented as mean \pm standard deviation; within a row, the means followed by the same letter are not significantly different by DMRT at $\mathrm{p}=0.05$.

Average fruit lengths of Embul, Seeni and Kolikuttu cultivars are $10.5 \pm 0.86,10.5 \pm 0.86$ and $14.3 \pm 1.66 \mathrm{~cm}$, respectively (Table 3 ). The diameter of the fruit is less at both ends and the maximum diameter was at the middle of the fruit (Table 3). This pattern was reported by Kachru. et al. (1995), for few other crop varieties as well. The fruit length and GMD of the 
Kolikuttu cultivar was significantly higher $(\mathrm{p}<0.05)$ than those of other two cultivars. The physical dimensions of fruits are useful in designing processing machines (Owolarafe and Shotonde, 2004). , and especially the data on fruit size are important in the design of grading and sorting equipment in the banana industry. Further, the fruit or finger length has been used to assess the maturity of the bunch before harvest (Dadzie and Orchard, 1997).

Table 3. Linear dimensions of banana fruits of three local cultivars

\begin{tabular}{|c|c|c|c|}
\hline \multirow{2}{*}{ Property } & \multicolumn{3}{|c|}{ Banana cultivars } \\
\hline & Embul & Seeni & Kolikuttu \\
\hline Length (cm) & $10.89^{b}$ & $10.46^{b}$ & $14.25^{\mathrm{a}}$ \\
\hline Diameter at top $(\mathrm{cm})^{*}$ & $3.13 \pm 0.28$ & $3.14 \pm 0.27$ & $3.43 \pm 0.29$ \\
\hline Diameter at middle $(\mathrm{cm})^{*}$ & $3.46 \pm 0.16$ & $3.39 \pm 0.15$ & $3.84 \pm 0.17$ \\
\hline Diameter at tail $(\mathrm{cm})^{*}$ & $3.28 \pm 0.18$ & $3.17 \pm 0.15$ & $3.35 \pm 1.05$ \\
\hline Geometrical mean diameter $(\mathrm{cm})$ & $3.28^{\mathrm{b}}$ & $3.23^{\mathrm{b}}$ & $3.45^{\mathrm{a}}$ \\
\hline
\end{tabular}

*Data presented as mean \pm standard error. Within a row, the means followed by the same letter are not significantly different at $=0.05$

\section{Sphericity and aspect ratio}

The average sphericity values were not significantly different $(\mathrm{p}>0.05)$ among three cultivars (Table 4). Sphericity of banana fruits showed was low compared to many other fruits due to their natural elongated-oblong shape (Sultani et al., 2011) as well. The sphericity values of banana fruits observed in this study are closer to those reported by Santosa et al. (2006), at the harvest maturity. Proper understanding on these parameters is important, as modern packaging must comply with the shape of fruits (Wills et al., 1989).

Table 4. Sphericity and aspect ratio of banana fruits

\begin{tabular}{lccc}
\hline \multirow{2}{*}{ Properties } & \multicolumn{3}{c}{ Banana cultivars } \\
\cline { 2 - 4 } & $0.37 \pm 0.02$ & Seeni & Kolikuttu \\
\hline Sphericity* & $23.24 \pm 2.34$ & $0.38 \pm 0.02$ & $0.37 \pm 0.03$ \\
Aspect ratio* & $25.69 \pm 2.23$ & $23.89 \pm 2.51$ \\
\hline
\end{tabular}

Values presented as mean \pm standard error.

\section{Volume and gravimetrical properties of banana}

The true density and bulk density of banana are useful during separation and transportation by hydronamic means (Owolarafe and Shotonde, 2004), especially in improving the packaging density of fruits in containers and in trucks. As shown in Table 5, the true density of 'Seeni' cultivar is significantly higher $(\mathrm{p}<0.05)$ than that of 'Embul' and 'Kolikuttu'. The bulk densities of three banana cultivars are significantly different $(\mathrm{p}<0.05)$ from each other at the harvest maturity. The mass and volume of banana bunches are significantly higher $(\mathrm{p}<0.05)$ for 'Kolikuttu' and 'Embul' cultivars than for 'Seeni'. 
Physical Properties of Sri Lankan Banana Cultivars

Table 5. Average volume and gravimetrical properties of banana bunches

\begin{tabular}{lrrr}
\hline \multirow{2}{*}{ Properties } & \multicolumn{3}{c}{ Banana cultivars } \\
\cline { 2 - 4 } & \multicolumn{1}{c}{ Embul } & Seeni & Kolikuttu \\
\hline Volume $(\mathrm{L})$ & $16.60^{\mathrm{a}}$ & $8.33^{\mathrm{b}}$ & $18.75^{\mathrm{a}}$ \\
Mass $(\mathrm{kg})$ & $17.16^{\mathrm{a}}$ & $9.62^{\mathrm{b}}$ & $19.50^{\mathrm{a}}$ \\
Bulk density $\left(\mathrm{kg} \mathrm{m}^{-3}\right)$ & $154.77^{\mathrm{c}}$ & $173.36^{\mathrm{b}}$ & $201.07^{\mathrm{a}}$ \\
True density $\left(\mathrm{kg} \mathrm{m}^{-3}\right)$ & $1034.48^{\mathrm{b}}$ & $1158.1^{\mathrm{a}}$ & $1040.99^{\mathrm{b}}$ \\
\hline
\end{tabular}

Within a row, the means followed by the same letter are not significantly different at $=0.05$

The true density of the hands of 'Embul' and 'Kolikuttu' cultivars are significantly lower $(p<0.05)$ than that of the 'Seeni' cultivar. These differences could at least partly be due to the presence of air voids between the peel and pulp of these two cultivars as reported by Kachru et al. (1995), as other variables are more or less similar.

Table 6. Volume and gravimetrical properties of banana hands

\begin{tabular}{|c|c|c|c|}
\hline \multirow{2}{*}{ Properties } & \multicolumn{3}{|c|}{ Banana cultivars } \\
\hline & Embul & Seeni & Kolikuttu \\
\hline Volume (L) & $0.906^{\mathrm{b}}$ & $0.765^{b}$ & $1.55^{\mathrm{a}}$ \\
\hline Mass (kg) & $1.11^{\mathrm{b}}$ & $1.038^{\mathrm{c}}$ & $1.76^{\mathrm{a}}$ \\
\hline Bulk density $\left(\mathrm{kg} \mathrm{m}^{-3}\right)$ & $335.44^{\mathrm{a}}$ & $337.46^{\mathrm{a}}$ & $341.66^{\mathrm{a}}$ \\
\hline True density $\left(\mathrm{kg} \mathrm{m}^{-3}\right)$ & $1246.42^{\mathrm{b}}$ & $1401.58^{\mathrm{a}}$ & $1133.50^{\mathrm{b}}$ \\
\hline
\end{tabular}

Within a row, the means followed by the same letter are not significantly different at $=0.05$

The fruit volume and mass of 'Kolikuttu' type banana are significantly higher than that of 'Seeni' and 'Embul' cultivars. The fruit finger bulk density of 'Kolikuttu' is the lowest compared to other two cultivars (Table 7). Fruit size of 'Kolikuttu' was the largest and therefore, the porosity is relatively higher when placed in a container. Baryeh (2002) has also reported that true density of fruits linearly increases with moisture content, and size of fruit influences the bulk density.

These results indicated that the bulk densities of fruits and hands of banana are higher than bulk density of the bunch. This proves the fact that transporting and storing individual banana fruits or as hands is economical than handling them as whole bunches. According to Tarighi et al. (2010), the packing coefficient decreases with increasing fruit volume, due to less air space left among the fruits.

Table 7. Volume and gravimetrical properties of banana fruits

\begin{tabular}{lrrr}
\hline \multirow{2}{*}{ Properties } & \multicolumn{3}{c}{ Banana cultivars } \\
\cline { 2 - 4 } & \multicolumn{1}{c}{ Embul } & Seeni & Kolikuttu \\
\hline Volume $\left(\mathrm{cm}^{3}\right)$ & $70.38^{\mathrm{b}}$ & $66.79^{\mathrm{b}}$ & $132.84^{\mathrm{a}}$ \\
Mass $(\mathrm{g})$ & $72.28^{\mathrm{b}}$ & $68.80^{\mathrm{b}}$ & $133.16^{\mathrm{a}}$ \\
Bulk density $\left(\mathrm{kg} / \mathrm{m}^{3}\right)$ & $494.45^{\mathrm{b}}$ & $476.63^{\mathrm{b}}$ & $342.00^{\mathrm{a}}$ \\
True density $\left(\mathrm{kg} / \mathrm{m}^{3}\right)$ & $1025.80^{\mathrm{b}}$ & $1344.47^{\mathrm{a}}$ & $1008.22^{\mathrm{b}}$ \\
\hline
\end{tabular}

Within a row, the means followed by the same letter are not significantly different at $=0.05$ 


\section{Coefficient of static friction}

The mean coefficient of static friction of banana bunches on wood, steel and Styrofoam surfaces are presented in the Table 8 . The highest values of friction coefficient of the three cultivars were recorded on a wooden surface, which is significantly higher $(\mathrm{p}<0.05)$ than on other two surfaces. The coefficient of static friction of three cultivars is significantly different $(p<0.05)$ on the three surfaces. The coefficients of static friction on Styrofoam for all three banana types are lower than on the other two surfaces indicating the smooth contact between fruit and material. The frictional properties are useful in designing partitions, lining materials and in bulk transportation of fruits in trucks (Jahromi et al., 2008). However, the coefficient of static friction of agricultural materials depends on the moisture content of produce at the time of testing (Dutta et al., 1988).

Table 8. Coefficient of static friction of banana bunches on different surfaces

\begin{tabular}{lccc}
\hline \multirow{2}{*}{ Properties } & \multicolumn{3}{c}{ Banana cultivars } \\
\cline { 2 - 4 } & Embul & Seeni & Kolikuttu \\
\hline Wood & $0.54^{\mathrm{a}}$ & $0.54^{\mathrm{a}}$ & $0.52^{\mathrm{b}}$ \\
Steel & $0.50^{\mathrm{c}}$ & $0.53^{\mathrm{abc}}$ & $0.49^{\mathrm{d}}$ \\
Styrofoam & $0.49^{\mathrm{d}}$ & $0.45^{\mathrm{e}}$ & $0.45^{\mathrm{e}}$ \\
\hline
\end{tabular}

Within a row and a column the means followed by the same letter are not significantly different at $=0.05$

\section{Fruit firmness}

Firmness of mature green banana fruits at the harvest maturity are $73.43 \mathrm{~N}( \pm 8.63)$ at 77.9 $\%$ of moisture content for 'Embul', $69.12 \mathrm{~N}( \pm 10.44)$ at $72.5 \%$ of moisture content for 'Seeni' and $77.15 \mathrm{~N}( \pm 7.32)$ at $76.0 \%$ moisture content for' Kolikuttu' fruits. Similar values of banana fruit firmness is reported by Sultani et al, (2010). Perera et al. (1999) have determined the fruit firmness of these banana cultivars by using a hand held penetrometer (Forestry Suppliers Inc.UK) and reported a higher fruit firmness value for 'Kolikuttu' cultivar than that of the other two cultivars. Santosa et al. (2006) have reported that the composition of fruit tissue determines the hardness of fruit. Armstrong et al. (1997), reported that the consumers rate firmness as one of the most important quality attributes when selecting fruits along with colour and aroma.

\section{CONCLUSIONS}

The bana cultivars 'Kolikuttu' and 'Embul' have large bunch size than the 'Seeni' cultivar while 'Kolikuttu' has the largest fruit size among the three cultivars tested. The sphericity and aspect ratio of banana fruits of three cultivars are lower than those of many other fruits as the banana fruit is elongated in shape. The bulk density of the whole bunches is lower than that of the hands and individual fruit fingers and therefore, separation of hands or fruits will increase the packing density, reduce the cost of transport and storage space. The highest coefficient of static friction and angle of repose for three banana cultivars are on wooden surface and the lowest on Styrofoam sheet surface and therefore, Styrofoam it could be used to minimize abrasion damages on fruit surfaces. The geometrical and gravimetrical properties of banana depend mainly on the cultivar. 


\section{REFERENCES}

Al-Hosni, A.S., Al-Busaid, I.K., Al-Farsi, M., Al-Jabri, M. and Al-Azri, H. (2010). Postharvest characteristics and qualities of selected banana (Musa spp.) cultivars in Oman. Proc. Int. Conf. Banana and Plantain in Africa. Acta Hort. 879: pp 407-411.

AOAC (1984). Official methods of analysis. 14th ed., VA, USA: Association of Official Analytical Chemists, Arlington.

Armstrong, P.R., Stone, M.L. and Brusewitz, G.H. (1997) Peach firmness determination using two different nondestructive irrational sensing instruments. Transactions of ASAE. 40(3), 699-703.

Baryeh, E.A. (2002). Physical properties of millet. Journal of Food Engineering. 51, 39-46.

Dadzie, B.K. and Orchard, J.E. (1997). Routing postharvest screening of banana/plantain hybrids: criteria and methods. INIBAP technical guidelines No. 2. INIBAP, Montpelier.

Dharmasena, D.A.N. and Rathnayake, H.C. (2004). Effect of environmental temperature variation on pysico-chemical properties of tomato in a Sri Lankan marketing channel. J. Agric. Eng. 8, 40-48.

Dharmasena, D.A.N. and Sarananda, K.H. (2012). Present status, Issus, and future trends in fruit and vegetable handling, distribution and marketing in Sri Lanka. Workshop on postharvest technology and cold chain management. 20-22 March 2012, Amity International Centre for Postharvest Technology and Cold Chain Management, Noida, India. Available at http://www.fruits.soton.ac.uk/?page_id=111

Dutta, S.K., Nema, V.K . and Bhardwaj, R.K . (1988). Physical properties of gram. J. Agric Eng. 39, 259-268.

Ekanayake, S. and Bandara, L. (2002). Development of banana leather. Annals of the Sri Lanka Department of Agriculture, 4, 353-358.

Fraser, B.M., Vermat, S.S. and Mutr, W.E . (1978). Some physical properties of faba beans. J. Agric. Eng. Res. 23, 53-57.

Hirimburegama, W.K., Dias, W.K.G. and Hirimburegama, K. (2004) Banana improvement through gamma irradiation and testing for banana bract mosaic virus in Sri Lanka. FAO corporate document repository, Available at http:/www.fao.org/docrep/007/ae216e/ ae216e09.htm\#TopOfPage.

Ikegwu O.J. and Ekwu, F.C. (2009). Thermal and physical properties of some tropical fruits and their juices in Nigeria. Journal of Food Technology. 7(2), 38-42.

Jahromi, M.K., Mohtasebi, S.S., Jafari, A.R.M. and Rafiee. S. (2008). Determination of some physical properties of date fruit (cv.Mazafati). J. of Agric. Tech. 20, 1-9.

Kachru, R.P., Gupta, R.K. and Alam, A. (1994). Physico-chemical constituents and engineering properties of food crops. Scientific publishers, Jodhpur, India. 
Kachru, R. P., Nachiket, K. and. Balasubramanian, D. (1995). Physical and mechanical properties of green banana (Muss paradisiaca). Fruit J. of F. Eng., 26, 369-378.

Kajuna, S.T.A.R., Bilanski, W.K. and Mittal G.S. (1997). Textural changes of banana and plantain pulp during ripening. J. Sci. Food Agri., 75, 244-250.

Kudagamage, C., Chandrasiri, G.W.J. and Razmy, A.M.Z. (2002). Analysis of long-term trends in banana sector of Sri Lanka, Annals of the Sri Lanka Department of Agriculture, 4, 21-32.

Maduako, J.N. and Faborode, M.O. (1990). Some physical properties of cocoa pods in relation to primary processing. Ife. J. Technol., 2(1), 1-7.

Mohsenin, N.N. (1970). Physical Properties of Plant and Animal Materials. Gordon and Breach Sci. Publishers, New York.

Mohsenin, N.N. (1986). Physical Properties of Plant and Animal Materials. Gordon and Breach Press, New York.

Owolarafe, O.K. and Shotonde, H.O. (2004). Some physical properties of fresh okra fruit. J. of F. Eng. 63, 299-302.

Owolarafe, O.K. Olabigeand, T.M. and Faborode, M.O. (2007). Macro-structural characterization of palm fruit at different processing conditions. J. of Food Eng. 78, 12281232 .

Perera, O.D.A.N., Basnayake, B.M.K.M.K. and Anjani, M. (1999). Physicochemical characteristics, popularity and susceptibility to anthracnose of some local banana cultivars. J . Natn. Sci. Foundation Sri Lanka, 27(2), 119-130.

Peleg, M. and Bagley, B. (1983). Physical Properties of Foods. AVI Publishing Company, Westport, CT.

Sahay, K.M. and Singh, K.K. (2005). Unit operations of agricultural processing, $2^{\text {nd }}$ Ed. Vikas Publishing Pvt.Ltd, New Delhi.

Santosa, A. and Deswita, D. (2006). Study of harvesting and ripening of banana to some physical parameters, Conference and international seminar in Medan, Indonesia, 22-23 June.

Sarananda, ,K.H. (2000). Country paper - Sri Lanka. Report of the APO seminar on appropriate postharvest technologies for orticultural crops in Asia.5-9 July, 1999. Bankgok, Thailand. Pp 230-236.

SAS (1994).Statistical Analysis of Software Programme Packages (SAS Institute version, $6.0)$.

Shewfelt, R.L., Meyers, S.C. and Resurreccion, A.V.A. (1987). Effect of physiological maturity at harvest on peach quality during low temperature storage. J. Food Qual. 10(1), 920. 
Stroshine, R. (2005). Physical Properties of Agricultural Materials and Food Products (Teaching material). Dept. Agric. Eng., Purdue Univ., West Lafayette, IN 47907, USA.

Sultani, M., Alimardani, R. and Omid, M. (2010). Comparison of some chromatic, mechanical and chemical properties of banana fruit at different stages of ripeness. Modern Applied Science, 4(7), 34-41.

Sultani, M., Alimardani, R. and Omid, M. (2011). Modeling the main physical properties of banana fruit based on geometrical attributes, Int. J. Multidisciplinary Sci. and Eng, 2(20), 16.

Tarighi, J., Mohtasebis, S., Heydari, H. and Abasghazvini, M. (2010). Physical properties of nectarine fruit (cv. Sunkinkg) to characterize best post harvesting Option. The Journal of Agricultural Science,. 43(2), 97-101.

Wills, R.H.H., McGlasson, W.B., Graham, D., Lee, T.H. and Hall, E.G. (1989). Postharvest: An Introduction to the Physiology and Handling of Fruit and Vegetables. Third Ed. Blackwell Scientific Publications, Oxford. 